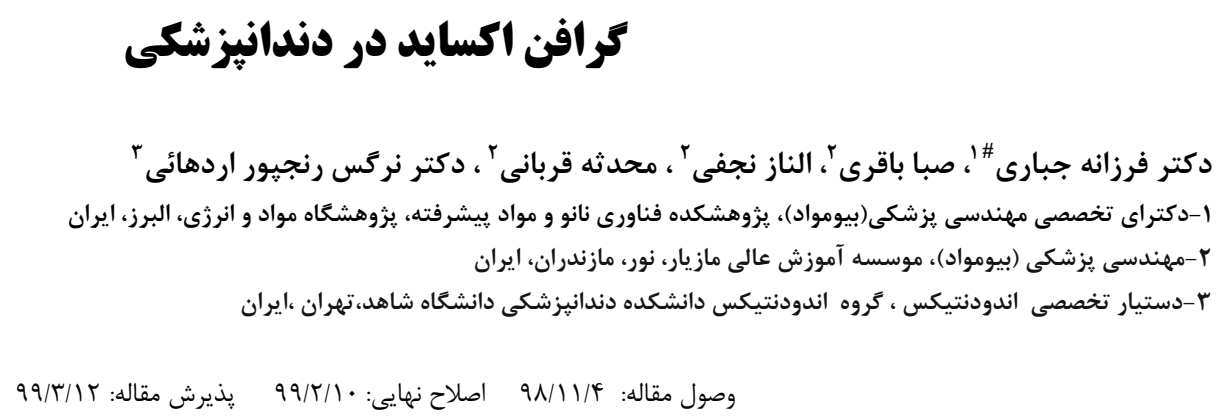

\title{
Graphene Oxide in Dentistry: A Review
}

Farzaneh Jabbari $^{\# 1}$, Saba Bagheri ${ }^{2}$, Elnaz Najafi ${ }^{2}$, Mohadeseh Ghorbani ${ }^{2}$, Narges Ranjpoor Ardehaee ${ }^{3}$

${ }^{1}$ Ph.D of biomedical engineering (biomaterial), Nanotechnology and Advanced Materials Department, Materials and Energy Research center (MERC), Alborz, Iran.

${ }^{2}$ Biomedical engineering (biomaterial), Maziar Institute of Higher Education, Noor, Mazandaran, Iran ${ }^{3}$ Postgraduate Student, Department of Endodontics School of Dentistry Shahed University, Tehran, Iran

Received: Jan 2020

; Accepted: May 2020

\section{Abstract}

Background and Aim: In this study, a brief but accurate evaluation of the role of graphene oxide in dentistry and interaction with all soft and hard tissues, the study of studies conducted in vitro or in vivo and new approaches in the field of tissue engineering has been investigated

Material \& Methods: Reviewed articles using Medline, Google scholar, Scopus, Science Citation Index and Magiran Embase databases and the keywords of graphene oxide, antibacterial material, tissue engineering and dentistry from 2015 to 2020 which includes 28 complete articles and 6 abstracts were gathered.

Results: The addition of graphene oxide to dental fillers or bone tissue regenerating membranes has provided acceptable results in many cases. In discussing mechanical properties, the addition of graphene oxide increases the mechanical strength and also improves the physical stability of the structure. Graphene and graphene based materials have shown toxic effects on hard and soft tissue cells, which are necessary for clinical applications, the optimal concentration of this oxide.

Conclusion: Adding graphene to dental materials was developed to increase their resistance to corrosion and improve their mechanical properties, but there was conflicting information about the cytotoxicity of graphene.

Keywords: Graphene Oxide, Antibacterial agents, Tissue Engineering

*Corresponding Author: jabarifarzane@yahoo.com

J Res Dent Sci. 2020; 17 (2): 154-161 
خلاصه:

سابقه و هدف : دراين مطالعه به صورت اجمالى ولى دقيق به بررسى نقش كرافن اكسيد در دندانيزشكى و بر هم كنش با تمامى بافت

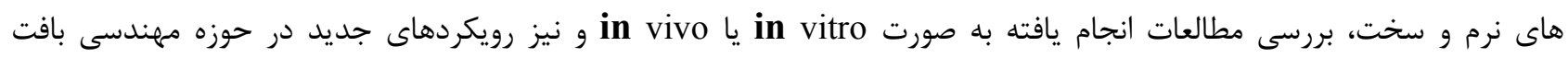
يرداخته شده است.

مواد وروش ها: مقـالات موردبـررسى با استفـاده ازيـايكاه هـاى اطلاعـاتـى Science ، Scopus ،Google scholar ، Medline

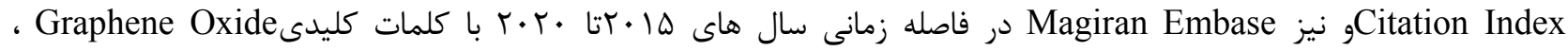
(Tissue Engineering ،Antibacterial Material يافته ها: افزودن گرافن اكسيد در مواد يركننده دندانى يا غشاهاى بازسازى كننده بافت استخوان در بسيارى از موارد نتايج قابل قبولى عالى ارائه نموده است. در بحث خواص مكانيكى، افزودن كرافن اكسيد موجب افزايش استحكام مكانيكى شده و نيز بايدارى فيزيكى ساختار را بهبود مى بخشد. گرافن و مواد بر پايه ى گرافن ، اثرات سمى بر روى سلول هاى بافت هاى سخت و نرم نشان داده اند كه براى

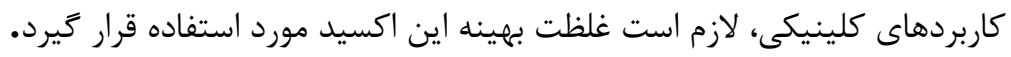
نتيجه كيرى: افزودن گرافن به مواد دندانيزشكى، باعث افزايش مقاومت آنها در برابر خوردىى و همجنين بهبود خواص مكانيكى آنها مى شود، اما اطلاعات ضد و نقيضى در مورد سميت سلولى كرافن وجود دارد.

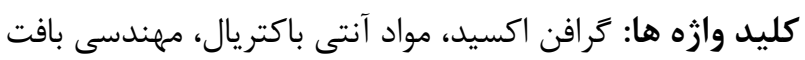

كرافن، يك لايه از اتم هاى مرتب شده كربن با هيبريد يك لانه زنبورى شكل و شبكه كريستالى دو بعدى است و

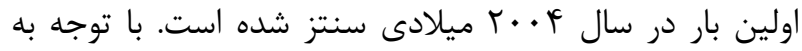
ساختار منحصر به فرد و هندسى اين ماده، ميتوان انتظار داشت بـان كرافن داراى خواص فيزيكى و شيميايى قابل توجه از جمله؛ مدول يانغ بالا، استحكام شكست بالا، هدايت بسيار عالى

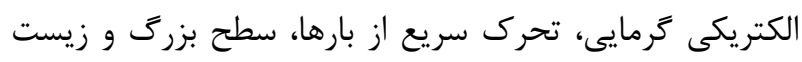

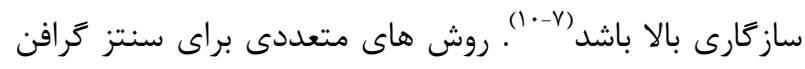
اكسيد گزارش شده است. سونيكيت اكسيد گرافيت در دى متيل فرم آميد و يا آب با خلوص بسيار بالا منجر به ايجاد كرافن اكسيد مى شود. روش ديخر، اكسيزن دار كردن كرافيت از طريق يكى از سه روش توسعه يافته توسط برودى، استدنمير

$$
\text { و هامرز مى باشد (I', II'). }
$$

با توجه به ويزگى هاى منحصر به فرد اين اكسيد، امروزه كاربردهاى فراوانى در حيطه مهندسى بافت، دندانيزشكى و نيز رهايش هدفمند دارو ززارش شده است. اگر داروها به روشى

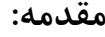

كربن، جهارمين عنصر فراوان در طبيعت است و يكى از عناصر بسيار ضرورى براى حيات انسان است. اين عنصر داراى ساختارهايى متفاوتى است كه به آنها آلوتروب هاى كروي كرين

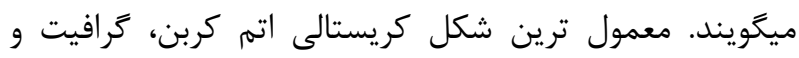
الماس است. كرافيت، آلوتروٍ سه بعدى كربن بوده كه داراى

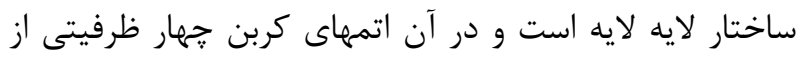
طريق سه يِيوند كووالانسى به سه اتم كربن ديكر متصل شده اند و يك ساختار شبكه اى شش كوشه اى را تشكيل مى

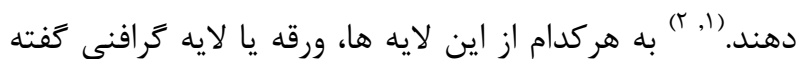
مى شود. هر ورقه به صورت موازى روى ورقه ديكر قرار گرفته و موجب ايجاد يك شبكه با توالى AB ميكردد. بدين ترتيب

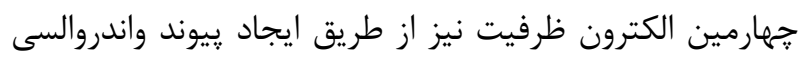

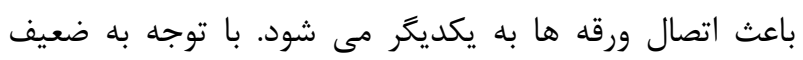
بودن پِيوندها بين ورقه هاى گرافنى (پيوندهاى واندروالسى)، ورقه هاى فوق مى توانند به راحتى روى همديخر بلغزند (r-"؟).

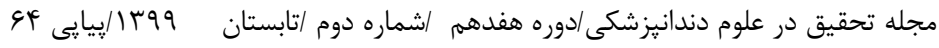




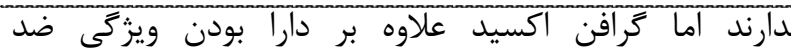
باكتريائى، موجب افزايش استحكام مكانيكى و تسريع در فرآيند

انزيوزنز مى گردد (1) هدف از اين مقاله، مرورى بر خواص و كاربردهاى گرافن اكسيد در حيطه دندانيزشكى و بررسى نتايج گاها متناقض ذكر شده تا به امروز مى باشد.

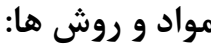

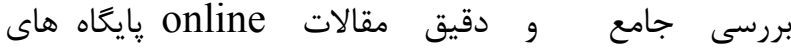
اطلاعاتى مانند Medline ، Google scholar ،Scopus، Science Citation Index فاصله زمانى سال هاىه| •r تا •r •r با كلمات كليدى AAntibacterial Material ،Graphene Oxide و Tissue Engineering

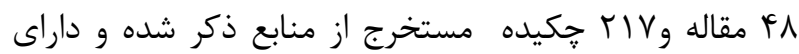
كلمات كليدى بيان شده در متن ، از نظر نتايج كاربردى در حيطه دندانيزشكى و مهندسى بافت نرم و سخت دهان مورد

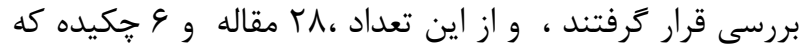
اطلاعات كامل و ضرورى در اين رابطه داشتند انتخاب شده و در نغارش متن نهايى استفاده شدند.

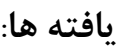
جهت استفاده از گرافن و اكسيد گرافن در كاربردهاى بالينى، ضرورى است كه اطلاعاتى در زمينه سميت و زيست سازگارى اين مواد در مدل هاى سلولى و حيوانى به دست آوريم. بسيارى از گزارش ها نشان مى دهد كه گرافن و سازه تركيبى از مشتقات گرافنى براى كاربردهاى دندانيزشكى، سميت كمى از خود نشان داده اند. مطالعات نشان مى دهد كه افزايش حلاليت و ديسيرسيتى گرافن و مشتقاتش موجب افزايش زيست سازگًارى مى شود. با اين حال اكسيد زَافن با داشتن زَروه هاى آبدوست إيوكسى، هيدروكسيل و اسيدى، زيست ساز گارى خود را بسيار بالا برده است. راهبرد تشكيل هيبريد گرافن و
مديريت شوند كه دقيقا نيازهاى فيزيولوزيكى را در زمان هاى مناسب و يا در محل مناسب برآورده سازند، بسيار مطلوب خواهد بود. يكى از حاملين دارو كه در دهه گذشته مورد توجه ويزه قرار گرفته، گرافن و مشتقات گرافن است كه زمينه متنوعى براى رسيدن به اهداف درمان كنترل محور ايجاد كرده است. ويزگى ها و خواص اين نانوحامل، شامل؛ شكل و هندسه منحصر به فرد، توانايى بارگيرى بالاى مواد زيستى، سنتز آسان و هزينه كم موجب افزايش كاربردهاى كلينيكى اين اكسيد

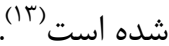

يكى از مهمترين كاربردهاى گرافن و اكسيد گرافن كه توجهات زيادى را در سال هاى اخير به خود جلب نموده است حوزه دندانيزشكى مى باشد. گرافن اكسيد به عنوان يركننده دندان و نيز به صورت كاميوزيت با يليمرهايى نظير كايتوسان و يا كلازن به عنوان غشاى بازسازى كننده استخوان يا بافت نرم يريودنتال مورد استفاده قرار مى گيرد. در حال حاضر ير كردن دندان با استفاده از آلياز هاى فلزى يا كاميوزيت هاى دندانى صورت مى گيرد. آليازهاى فلزى تيره رنگ هستند و از يودر آلياز حاوى فلزاتى مانند مس، نقره و قلع، همراه با تركيبات ديگرى كه براى اصلاح خواص آلياز مورد استفاده قرار مى كيرد، تشكيل شده اند و سال هاى طولانى است كه براى ير كردن استفاده مى شوند. مواد همرنت يا كاميوزيت، يايه رزين دارند و همرنت دندان هستند. معمولا هر دو شيوه يركردن دندان بسته به جنس مورد استفاده، به مرور زمان از بين مى روند و دوباره بايد ترميم شوند. مطالعات جديد نشان مى دهد كه مى توان براى يركردن دندان، از گرافن اكسيد استفاده كرد.

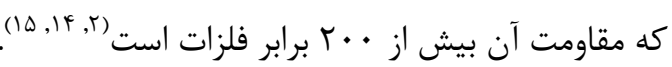
مطالعات آزمايشگاهى نشان داده كه گرافن اكسيد در مقايسه با كرافن سميت كمترى براى سلول ها و بافت هاى بدن دارد. نانو ذرات كرافن اكسيد داراى خواص آنتى باكتريال و انزيوزنز نيز مى باشند بنابراين مى توان در كاميوزيت هاى دندانى مورد استفاده قرار گيرد. تركيباتى مانند اكسيد روى كه به عنوان فاكتور آنتى باكتريال در تركيب كاميوزيت هاى دندانى مورد استفاده قرار ميخيرند تاثيرى بر خواص مكانيكى كاميوزيت 
با ناحيه آسيب ديده و سطح خارجى هر يك ويزگى هاى منحصر به فردى را دارا باشند. گرافن اكسيد علاوه بر خاصيت تحريك استخوان سازى، ويزگى آنتى باكتريال و بهببود دهنده

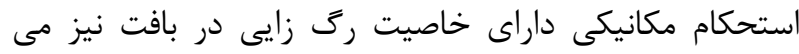
باشد و بنابراين مى توان براى اهداف جندكانه مورد استفاده قرار داد. Bai و همكارانش كاميوزيتى متشكل از ترافن اكسيد/فلورهيدروكسى آياتيت را به منظور بهبود عملكرد

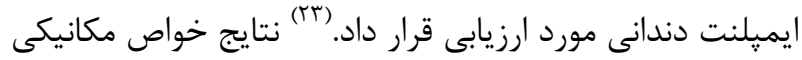
انجام شده نشان داد با اضافه كردن ترافن اكسايد و يون فلورين به هيدروكسى آياتيت خواص مكانيكى بهبود پِيدا كرده

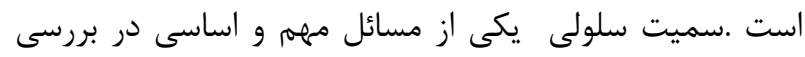
هاى يزشكى و دندانى مى باشد تا وجود سميت موجب بروز مشكلى در سيستم بدنى نداشته باشد.در اين تحقيق سميت

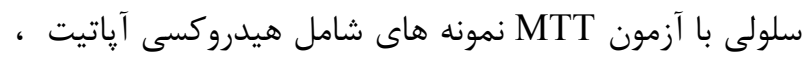
فلوروهيدروكسى آپاتيت، ترافن اكسيد افلوروهيدروكسى آياتيت مورد ارزيابى قرار گرفت.طبق نتايج اين آزمون، نمونه شامل كرافن اكسيد /فلوروهيدروكسى آياتيت بيشترين زنده

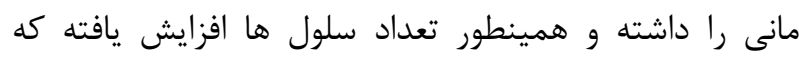
نشان دهنده ى تكثير سلولى است.از طرفى محققين فعاليت

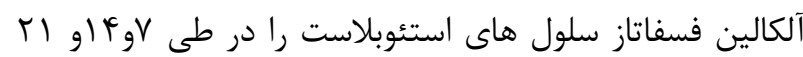
روز مورد بررسى قرار دادند و در روز أام كاميوزيت كرافن

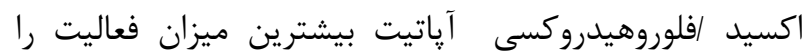
نشان داده است.خواص آنتى باكتريال سه نمونه نيز مورد بررسى قرار گرفت كه از بين نمونه ها،كاميوزيت گرافن اكسيد افلوروهيدروكسى آپاتيت كمترين ميزان جسبندكى به سطح

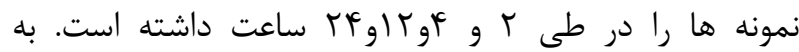
طور كلى طبق نتايج بدست آمده از اين تحقيق، كرافن اكسايد و يون فلورين در اين كاميوزيت(كاميوزيت كرافن اكسيد افلوروهيدروكسى آياتيت )نسبت به هيدروكسى اياتيت خالص

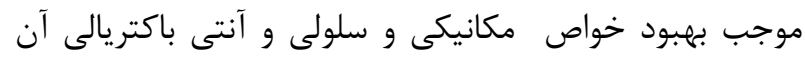

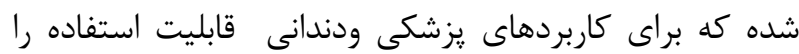

مشتقاتش با يليمرها براى بهبود زيست سازكارى مورد توجه

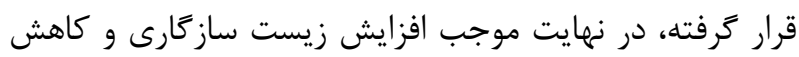

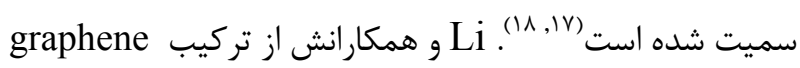
براى نشان دار سازى سلول هاى oxide quantum dots بنيادين جدا شده از بافت پالٍ دندان استفاده نموده و كمترين

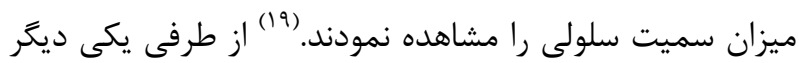
از ويزگى هاى بسيار مهم در دندانيزشكى ،استحكام مكانيكى مى باشد.Manarao و همكارانش زيركونياى پايدار شده با ايتريم را با كرافن اكسيد كاهش يافته يوشش داده و ميزان

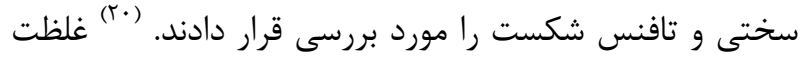

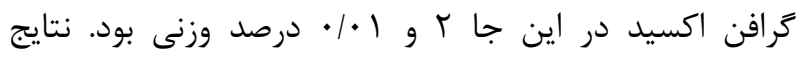
بررسى خواص مكانيكى نشان داد كه تغييرات غلظت خرافن اكسيد بر تافنس شكست كاملا بى تاثير بود. فرآيند اسيارك يلاسما موجب افزايش استحكام مكانيكى كاميوزيت ترافن اكسيد كاهش يافته/ زيركونياى קايدار شده با ايتريم خرديد. جبارى و همكارانش نيز كرافن اكسيد كاهش يافته را به صورت كاميوزيت با فيبروئين ابريشم و كايتوسان به عنوان غشاى بازسازى كننده بافت استخوان با روش ريخته گرى حلال

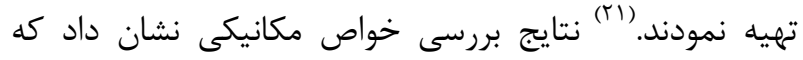
وجود كرافن اكسيد در ساختار موجب تردى غشاها شده و با مران افزايش غلظت كرافن اكسيد، استحكام كششى به شدت كاهش إنس مى يابد. نتايج بررسى رفتار سلولى نشان داد كه غلظت گرافن اكسيد كاهش يافته در غلظت ه/• درصد وزنى كاملا زيست ساز كار بوده و هيج كَونه سميتى براى سلول ها ندارد. با افزايش غلظت كرافن اكسيد ميزان فعاليت آلكالين فسفاتازى و نيز تراكم گره هاى كلسيمى تشكيل يافته افزايش يافت.. Meng Li را با تكنيك لايه به لايه تهيه نموده و قابليت تحريك استخوان

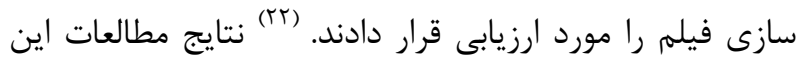

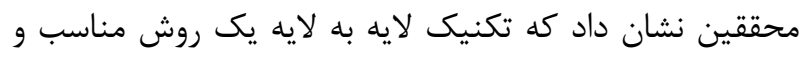
بسيار جذاب براى ساخت سازه هايى با ويزَّى هاى خند كانه بوده و به طور مثال مى توان غشاهاى بازسازى كننده بافت

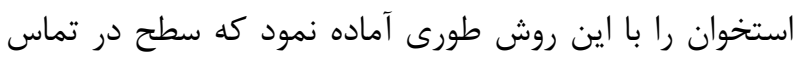

مجله تحقيق در علوم دندانيزشكى/دوره هفدهم /شماره دوم /تابستان 99 إيبايى 
استخوان سازى سلول هاى پآلٍ دندان، با تكنيك لايه به لايه

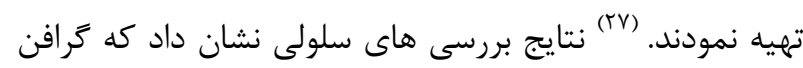

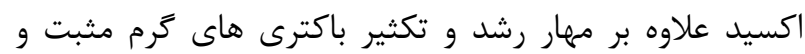

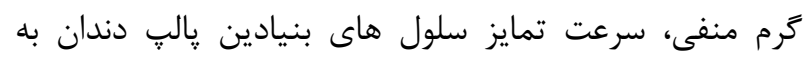

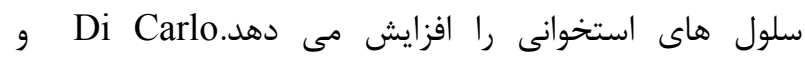

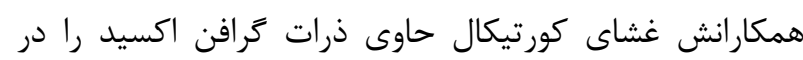
تماس با سلول هاى پالٍ دندان قرار داده و روند تكثير، تمايز و ورات

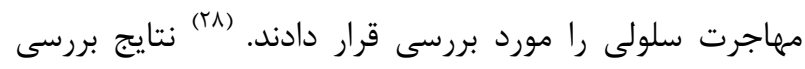

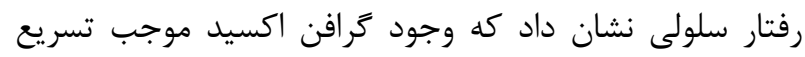

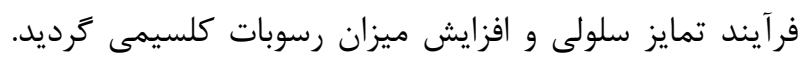
Yang و همكارانش تاثير گرافن اكسيد و كرافن اكسيد كوانتوم دات را بر فرآيند تمايز استخوانى سلول هاى بنيادين مشتق شده از دندان شيرى مورد بررسى و مطالعه قرار دادند. نتايج

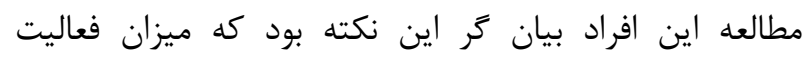
آلكالين فسفاتازى سلول ها، ميزان تشكيل كره هاى كلسيمى و ون رسوبات كلسيمى و نيز بيان زن سلول هاى در تماس با گرافن ميرن

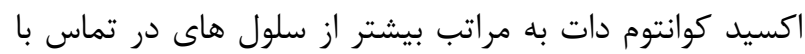

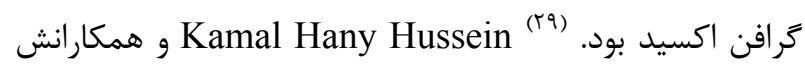
كرافن اكسيد التراسونيكه شده را براى ترميم بافت استخوان

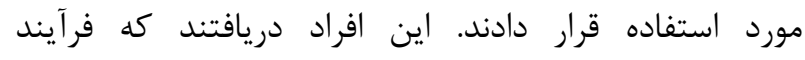
التراسونيك موجب شكستن ذرات شده و از تشكيل كلوخه و به هم جسبيدن ذرات جلوكيرى مى كند در نتيجه ذرات به راحتى درون آب يخش شده و واين در حالى است كه ذرات

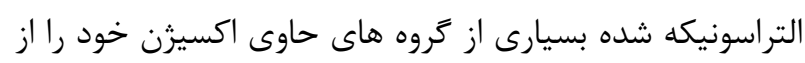

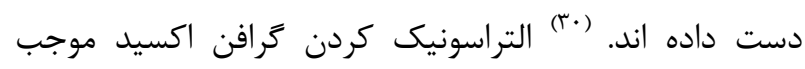

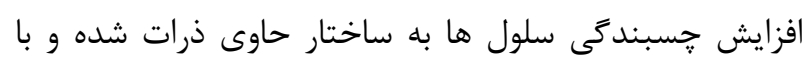

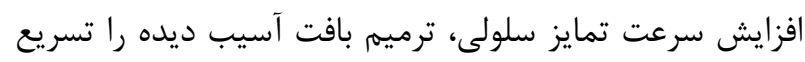
مى كندTahriri همكارانش در مطالعات خود مشاهده نمودند

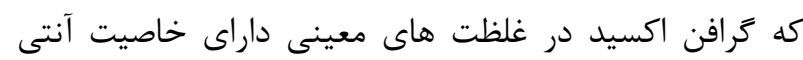
باكتريال بوده و در تماس با سلول هاى ايمنى موجب تحريك

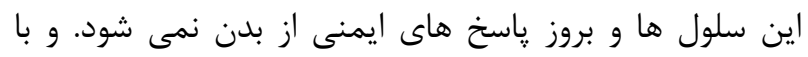

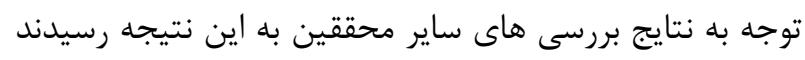

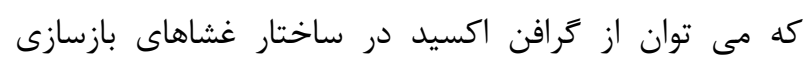

Jang-Hwan و همكارانش تركيبى أز يلى متيل متاكريلات و نانوذرات كرافن اكسيد را تهيه نموده و خواص آنتى ميكروبى و ضد جسبندگى را مورد بررسى قرار دادند.نتايج اين بررسى ها

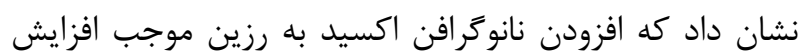

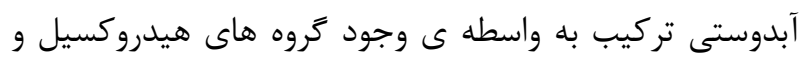

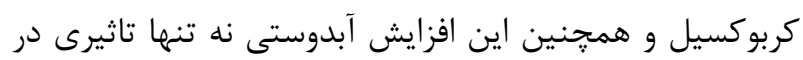
مقاومت خمشى و ميزان سختى سطح آن نشده بلكه از عفونت

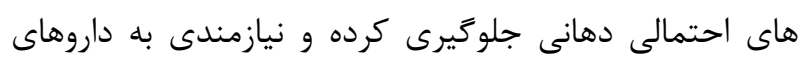
آنتى ميكروبى را از بين برده است. Y.Y.Shi (TF)

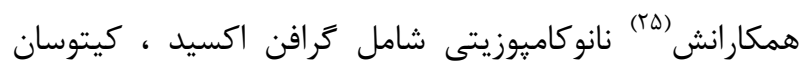

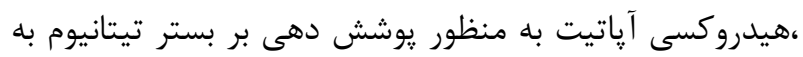

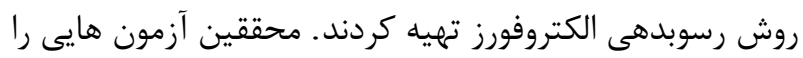

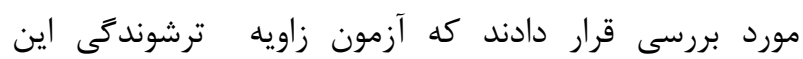

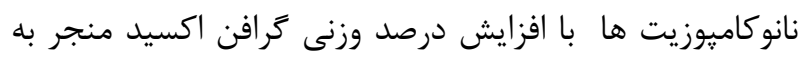

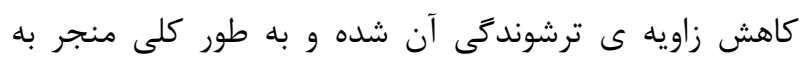

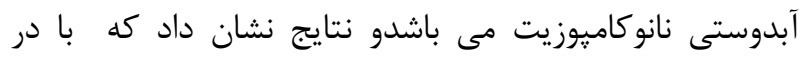

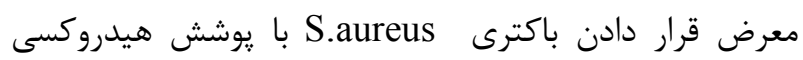

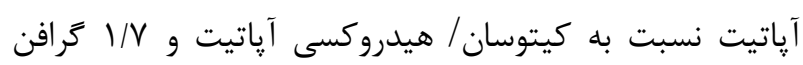
اكسيد /كيتوسان /هيدروكسى آياتيت به ترتيب خواص آنتى آنى

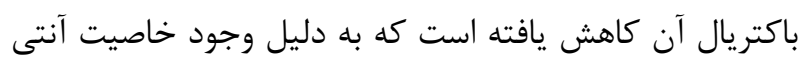
باكتريالى كيتوسان و گرافن اكسيد مى باشد .از طرفى آزمون سميت سلولى با استفاده از سلول هاى استخوانى بررسى قرار ترفت كه نتايج بررسى ها سميت معنادارى را نشان

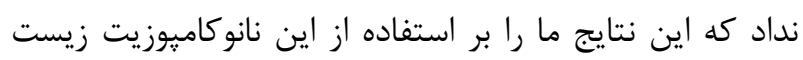
سازگًاردر حوزه ى دندانى و ارتويدى ترغيب مى كند. و همكارانش تاثير ترافن در مينراليزاسيون Linxi Zhang

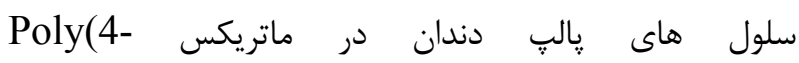
(1) رال در محيط آزمايشًاه مورد مطالعه قرار (vinylpyridine دادند. (1) نتايج نشان داد كه كرافن بيشتر از فاكتورهاى تمايز

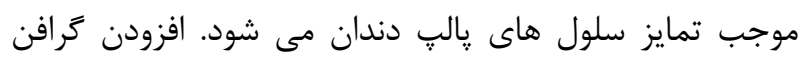

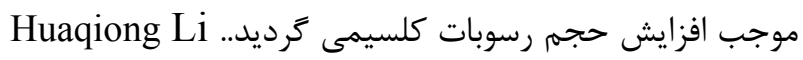
و همكارانش كاميوزيت ترافن اكسيد، تانيك اسيد و ليزوزيم را به عنوان يوششى با خاصيت آنتى باكتريال و تحريك كننده 
تومورها قابل استفاده هستند. اثر بخشى اين كاربردها بسته به

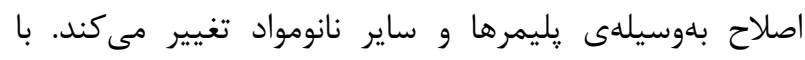
بررسىهاى انجام گَرفته ، اكسيد گَرافن نسبت به كرافن داراى برترىهايى از قبيل دارا بودن گروههاى عاملى آبدوستى است. مختصر سميت اكسيد كرافن را با اصلاح بلوسيلهى يليمرها و ساير نانوذرات مىتوان كاهش داد. . در زمينه مواد يركننده دندان، يركننده هاى فلزى معمولا از مخلوطى از فلزاتى مانند

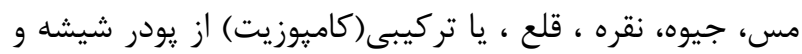

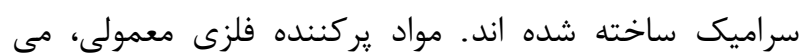

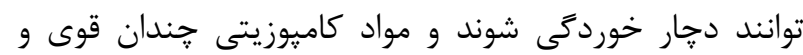

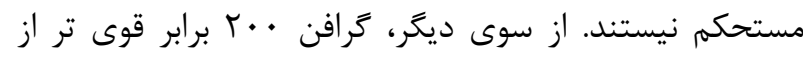
فولاد بوده و دجار تخريب و خوردىى نمى شود، اين خصوصيات آن را به يك نامزد درجه يك و جديد براى يركردن دندان ها تبديل كرده است. در زمينه تروتز دندانى نيز شايان ذكر است كه صنعت دندانيزشكى به دنبال مواد مقاومتر براى استفاده در يروتز دندان است، موادى كه بتواند مقاومت بالايى در برابر شرايط يرفشار دندانها داشته باشد. از سوى ديخر، بايد اين اطمينان حاصل گردد كه اين مواد موجب اثرات منفى بر بافتهاى آلى دهان نمىشوند. تاكنون تركيبات مختلفى مورد

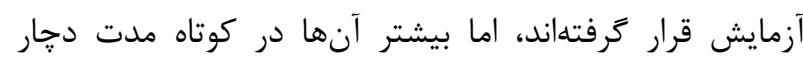
شكستخى شده يا واكنش آلرزىزا ايجاد نمودهاند. بنابراين، براى استفاده در دهان مناسب نبودهاند. كاميوزيت هاى يليمرى حاوى نانو ذرات كرافن و يا گرافن اكسيد كاربردهاى دندانى كسترداى يافته اند. پيليمر تقويت شده با گرافن مىتواند مشكلات و نقصهاى تركيبات مورد استفاده در يروتز دندان را رفع نمايد. با اين كار دوام ادوات به كار رفته در كاشت دندان افزايش يافته و تعداد جراحىهاى مورد نياز براى ترميم دندان

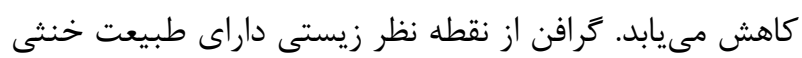

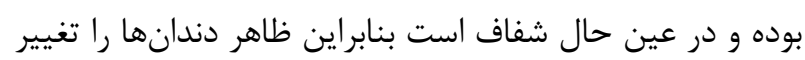
نمى دهد.
كننده استخوان، بافت نرم يريودنتال، در تركيب رزين ها و سيمان هاى دندانى، در يوشش هاى زيست فعال بر روى

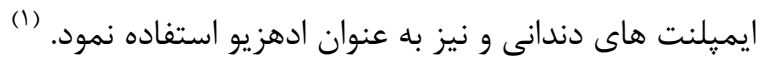
Vinicius Rosa .. سيمان هاى دندانى به اين نتيجه رسيدند كه افزودن گرافن اكسيد و نيز گرافن اكسيد كاهش يافته به تركيب سيمان موجب بهبود خواص فيزيكى- مكانيكى نهايى سيمان شده و

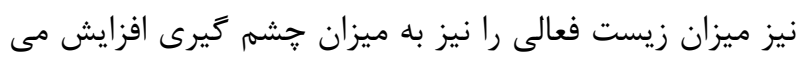

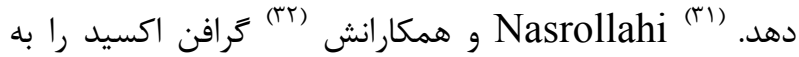
تركيب سيمان هاى براشيتى اضافه نمودند. سيمان براشيتى با ومدان مخلوط كردن بتا ترى كلسيم فسفات و مونو كلسيم فسفات تك آبه حاصل كرديد. گرافن اكسيد در غلظت هاى • ، ه/ • ، r و له درصد وزنى به تركيب سيمان افزوده شد. نتايج بررسى خواص مكانيكى نشان داد كه وجود گرافن اكسيد موجب افزايش استحكام فشارى سيمان ها شده و نيز بعد از غوطه ورى نمونه ها در محلول شبيه سازى شده بدن(SBF) رسوب هيدروكسى آياتيت روى سطح سيمان ها به مراتب بيشتر از سيمان خالص بوده و اين به معنى افزايش زيست فعالى سيمان در حضور ترافن اكسيد مى باشد. Zapata و همكارانش كرافن اكسيد را به سيمان اكريليك استخوانى اضافه نموده و مشاهده

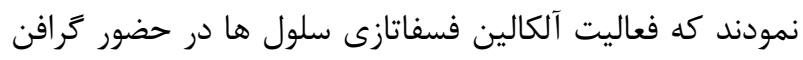

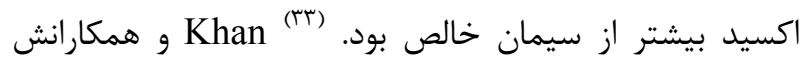
تاثير حضور كرافن اكسيد در باندينَ رزين به زيركونيا را مورد

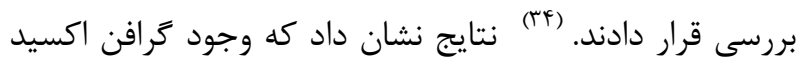
موجب افزايش زبرى سطح و افزايش قدرت اتصال رزين به

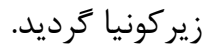

بحث: مطالعات انجام يافته طى سالهاى اخير در زمينه دندانيزشكى نشان داده كه كرافن و مواد بر קايه گَرافن مى توانند در بسيارى زمينه ها مثمر ثمر واقع شوند. گرافن و مشتقاتش، مواد يركاربردى بهعنوان يلتفرم زيستى نوين هستند كه در طيف

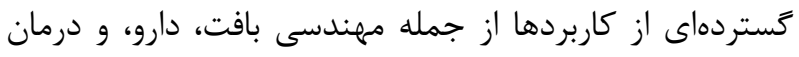

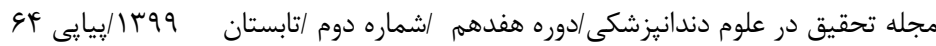


References:

1.Tahriri M, Del Monico M, Moghanian A, Yaraki MT, Torres R, Yadegari A, et al. Graphene and its derivatives: Opportunities and challenges in dentistry. Materials Science and Engineering: C. 2019.

2.Priyadarsini S, Mukherjee S, Mishra M. Nanoparticles used in dentistry: A review. Journal of oral biology and craniofacial research. 2018;8(1):58-67.

3.Ambrosio L, Raucci MG, Longo A, Carotenuto G, Giugliano D. Biocomposite of biomineralized graphene oxide and its use for bone tissue engineering. Google Patents; 2020.

4.Balaji M, Nithya $P$, Mayakrishnan A, Jegatheeswaran S, Selvam S, Cai Y, et al. Fabrication of Palladium Nanoparticles Anchored Polypyrrole Functionalized Reduced Graphene oxide Nanocomposite for Antibiofilm Associated Orthopedic Tissue Engineering. Applied Surface Science. 2020:145403.

5.Kashte S, Sharma R, Kadam S. Layer-by-layer decorated herbal cell compatible scaffolds for bone tissue engineering: A synergistic effect of graphene oxide and Cissus quadrangularis. Journal of Bioactive and Compatible Polymers. 2020:0883911519894667.

6.Satapathy MK, Manga YB, Ostrikov K, Chiang W-H, Pandey A, Nyambat B, et al. Microplasma cross-linked graphene oxide-gelatin hydrogel for cartilage reconstructive surgery. ACS Applied Materials \& Interfaces. 2020.

7.Qi C, Deng Y, Xu L, Yang C, Zhu Y, Wang G, et al. A sericin/graphene oxide composite scaffold as a biomimetic extracellular matrix for structural and functional repair of calvarial bone. Theranostics. 2020;10(2):741.

8.Viana AR, Salles B, da Silva Bruckmann F, Krause LMF, Mortari SR, Rhoden CRB. Cytotoxicity study of graphene oxide against vero lineage cells. Disciplinarum Scientia| Naturais e Tecnológicas. 2020;20(3):355-64.

9.Li J, Liu X, Crook JM, Wallace GG. Electrical stimulation-induced osteogenesis of human adipose derived stem cells using a conductive graphenecellulose scaffold. Materials Science and Engineering: C. 2020;107:110312.

10.Ali AA, Madkour M, Sagheer FA, Zaki MI, Abdel Nazeer A. Low-Temperature Catalytic CO Oxidation Over Non-Noble, Efficient Chromia in Reduced Graphene Oxide and Graphene Oxide Nanocomposites. Catalysts. 2020;10(1):105.

11.Szabo T, Maroni P, Szilagyi I. Size-dependent aggregation of graphene oxide. Carbon. 2020.

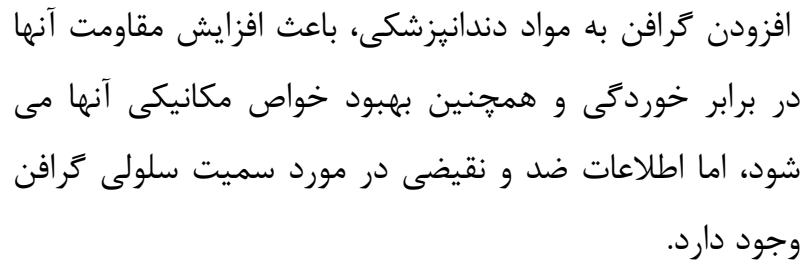


12.Kudus MHA, Zakaria MR, Akil HM, Ullah F, Javed F. Oxidation of graphene via a simplified Hummers' method for graphene-diamine colloid production. Journal of King Saud UniversityScience. 2020;32(1):910-3.

13.Chen Y, Yang Y, Xian Y, Singh P, Feng J, Cui $\mathrm{S}$, et al. Multifunctional Graphene-OxideReinforced Dissolvable Polymeric Microneedles for Transdermal Drug Delivery. ACS Applied Materials \& Interfaces. 2020.

14.Sarto MS, Polimeni A, Uccelletti D, BREGNOCCHI A, CHANDRAIAHGARI CR, ZANNI E, et al. Process for the production of antimicrobial dental adhesives including graphene and relative product thereof. Google Patents; 2019.

15.Alamgir M, Tiwari SK, Mallick A, Nayak G, editors. Graphene oxide and $\mathrm{TiO} 2$ based PMMA nanocomposites for dental applications: A comprehensive study of the mechanical properties. IOP Conference Series: Materials Science and Engineering; 2018: IOP Publishing.

16.Hsueh Y-H, Hsieh C-T, Chiu S-T, Tsai P-H, Liu C-Y, Ke W-J. Antibacterial Property of Composites of Reduced Graphene Oxide with Nano-Silver and Zinc Oxide Nanoparticles Synthesized Using a Microwave-Assisted Approach. International journal of molecular sciences. 2019;20(21):5394.

17.Martín C, Kostarelos K, Prato M, Bianco A. Biocompatibility and biodegradability of 2D materials: graphene and beyond. Chemical Communications. 2019;55(39):5540-6.

18.Liu Y, Peng J, Wang S, Xu M, Gao M, Xia T, et al. Molybdenum disulfide/graphene oxide nanocomposites show favorable lung targeting and enhanced drug loading/tumor-killing efficacy with improved biocompatibility. NPG Asia Materials. 2018;10(1):e458-e.

19.Li X, Guo H, Ren S, Fan R, Yu Y, Zhang H, et al. Fluorescent labelling in living dental pulp stem cells by graphene oxide quantum dots. Artificial cells, nanomedicine, and biotechnology. 2019;47(1):115-22.

20.MANARAO D, CORDEIRO G, TERTULIANO A, MACHADO I, LAZAR D, USSUI V, et al. YTZP reinforced with reduced graphene oxide. dental materials. 2019.

21.Jabbari F, Hesaraki S, Houshmand B. The physical, mechanical, and biological properties of silk fibroin/chitosan/reduced graphene oxide composite membranes for guided bone regeneration. Journal of Biomaterials Science, Polymer Edition. 2019;30(18):1779-802.

22.Li M, Li H, Pan Q, Gao C, Wang Y, Yang S, et al. Graphene Oxide and Lysozyme Ultrathin Films with Strong Antibacterial and Enhanced Osteogenesis. Langmuir. 2019;35(20):6752-61.
23.Bai Y, Bai Y, Gao J, Ma W, Su J, Jia R. Preparation and characterization of reduced graphene oxide/fluorhydroxyapatite composites for medical implants. Journal of Alloys and Compounds. 2016;688:657-67.

24.Lee J-H, Jo J-K, Kim D-A, Patel KD, Kim H-W, Lee $\mathrm{H}-\mathrm{H}$. Nano-graphene oxide incorporated into PMMA resin to prevent microbial adhesion. Dental Materials. 2018;34(4):e63-e72.

25.Shi Y, Li M, Liu Q, Jia Z, Xu X, Cheng Y, et al. Electrophoretic deposition of graphene oxide reinforced chitosan-hydroxyapatite nanocomposite coatings on $\mathrm{Ti}$ substrate. Journal of Materials Science: Materials in Medicine. 2016;27(3):48.

26.Zhang L, Feng K-C, Yu Y, Chuang Y-C, Chang C-C, Vadada $S$, et al. Effect of Graphene on Differentiation and Mineralization of Dental Pulp Stem Cells in Poly (4vinylpyridine) Matrix in Vitro. ACS Applied Bio Materials. 2019;2(6):2435-43.

27.Li H, Gao C, Tang L, Wang C, Chen Q, Zheng Q, et al. Lysozyme (Lys), tannic acid (TA), and graphene oxide (GO) thin coating for antibacterial and enhanced osteogenesis. ACS Applied Bio Materials. 2019.

28.Di Carlo R, Zara S, Ventrella A, Siani G, Da Ros T, Iezzi $\mathrm{G}$, et al. Covalent Decoration of Cortical Membranes with Graphene Oxide as a Substrate for Dental Pulp Stem Cells. Nanomaterials. 2019;9(4):604.

29. Yang X, Zhao Q, Chen Y, Fu Y, Lu S, Yu X, et al. Effects of graphene oxide and graphene oxide quantum dots on the osteogenic differentiation of stem cells from human exfoliated deciduous teeth. Artificial cells, nanomedicine, and biotechnology. 2019;47(1):822-32.

30.Hussein KH, Abdelhamid HN, Zou X, Woo H-M. Ultrasonicated graphene oxide enhances bone and skin wound regeneration. Materials Science and Engineering: C. 2019;94:484-92.

31.Rosa V, Rodríguez-Lozano FJ. Graphene to improve the physicomechanical properties and bioactivity of the cements. Advanced Dental Biomaterials: Elsevier; 2019. p. 599-614.

32.Nasrollahi N, Dehkordi AN, Jamshidizad A, Chehelgerdi M. Preparation of brushite cements with improved properties by adding graphene oxide. International Journal of Nanomedicine. 2019;14:3785.

33. Valencia Zapata ME, Hernandez M, Herminsul J, Grande Tovar CD, Valencia Llano CH, Diaz Escobar JA, et al. Novel bioactive and antibacterial acrylic bone cement nanocomposites modified with graphene oxide and chitosan. International journal of molecular sciences. 2019;20(12):2938.

34.Khan AA, Al-Khureif AA, Saadaldin SA, Mohamed BA, Musaibah AS, Divakar DD, et al. Graphene oxide-based experimental silane primers enhance shear bond strength between resin composite and zirconia. European Journal of Oral Sciences. 2019. 